\title{
A Study on Economic Analysis of Rural Green-village Planning using Solar Energy
}

\author{
태양에너지를 이용한 농촌 그린빌리지 계획의 경제성 분석에 관한 연구 \\ Kim, Dae-sik, * Nam, Sang-woon * \\ 김대식 - 남상운
}

\begin{abstract}
본 연구는 농촌마을을 환경친화적으로 계획하는데 활용할 수 있는 신재생에너지 중에서 태양에너지를 고려한 농촌그린빌리지 디자인에 대한 경제성분석을 목적으로 한다. 이 논문에서는 경제적 측면에서 에너지 수지를 고려하여 세 가지 형태의 연구대상 농촌마을에 대한 분석을 실시하였다. 연구대상 농촌마을들에서 실제로 사용했던 전체 에너지를 태양광 발전으로 대체하기 위한 태양광 발전시스템인 $3 \mathrm{kWp}$ 의 단위 모듈 (PV 시스템)의 개수들을 마을별로 추정하였다. 경제성 분석에서는 두 개 마을의 순현 재가치 (NPV)가 평가기간 25년내에 마이너스 값을 보였으며, 나머지 하나의 마을에서 경제성이 있는 것으로 분석되었다. 정부에 서 시설설치 보조금을 $60 \%$ 지원해 줄 경우에는 모든 마을에서 25 년 내에 경제성이 있는 것으로 평가되었다. 경제성 평가 관련 인자들에 대한 민감도 분석을 $\mathrm{BC}$ (Benefit/Cost) 비율 변화에 대하여 실시한 결과, 설치비용, 전력판매단가, 할인율, 단가 증가율 순으로 높은 변화율을 보였다. 본 연구의 결과는 태양에너지가 에너지 재활용이 가능한 농촌마을을 계획함에 있어서 정부의 적 절한 지원정책과 에너지 잠재력이 높은 농촌마을을 선별한다면 매우 효과적인 결과를 얻을 수 있다는 것을 보여준 것으로 판단 되었다.
\end{abstract}

Keywords: Economical analysis; green-village; renewable energy; solar energy

\section{INTRODUCTION}

Increase of fossil energy consumption and greenhouse effect of $\mathrm{CO}_{2}$ have been important issues that all nations in the world should take cooperation to decrease the amount of $\mathrm{CO}_{2}$. Such effort has led to develop new and renewable energy which can substitute fossil energy. The energy consumption in rural area of Korea has been increased continuously due to variable factors such as increasing life quality, using electronic products, and $\mathrm{ex}^{-}$ panding new heating system with more electricity energy. Korean government established the support policies for application of new and renewable energy until 2012. Particularly in Korean rural areas, the local government not only made a policy foundation which enable the green-village planning project to be expanded the main

\footnotetext{
* 충남대학교 농업생명과학대학 지역환경토목학과

$\dagger \quad$ Corresponding author Tel.: +82-42-821-5794

Fax: +82-42-821-8943

E-mail: swnam@cnu.ac.kr

2010년 5월 28일 투고

2010년 6월 28일 심사완료

2010년 6월 28일 게재확정
}

policy planning project through local energy projects, but also established a plan to construct 100 green-villages until 2012 (MAF, 2007).

Solar energy is the most useful resource that can be applied to rural green-village planning without using fossil energy. Thus for new policy promoting application of new and renewable energy, economical analysis to application of solar energy should be analyzed in viewpoint of recycling resources on rural areas. The green-village means that can generate the total amount of energy used in the village by using new and renewable energy. As one of the several case villages in Korea, Dongkwang village, which located on Jeju island, has 57 houses with total $143 \mathrm{~kW}$ of photovoltaic (PV) capacity by solar energy. The village is the first case village using solar energy in Korea constructed at November 2004 by subsidy of the government. The 57 houses' solar electricity systems generate $166,000 \mathrm{~kW} / \mathrm{yr}$ which can substitute $76 \%$ of total used energy in the village. As another case on using solar energy, the 111 houses' systems in Kwangju city, which located on south-west area of Korea, have generated $150 \mathrm{~kW}$ of electricity and 15,0001 of warm 
water, respectively, established by subsidy of the government and "Solar City" project of Kwangju city. There are also several more cases using solar energy such as Jecheon city and Woolju county for village unit constructed at 2007.

In various research aspects, the green-village planning for remodeling villages in Korea should be studied on several important factors such as resolving energy problem in rural areas, decreasing greenhouse effect with $\mathrm{CO}_{2}$, recycling resources, conserving ecosystem, and economical revenue. Ju et al (2006) investigated a long-term thermal performance of active solar hot water heating system for the dormitory of university. Lee and Kang (2006) studied on the analysis of long-term performance characteristics of various solar thermal system for heating protected horticulture system for reducing heating cost, increasing the value of product by environment control, and developing advanced culture technology by deploying solar thermal system. Kim et al. (2007) studied on payback period of solar power generation systems. Choi, et al. (2009) analyzed variation of NPV on 25 years of payback period. Nam and Kim (2007, 2008) studied energy amount used in rural villages and analyzed energy potential in the villages using solar energy. This study is focused on analyzing the energy balance in economical aspect, in order to accomplish multi purposes of rural remodeling policy, including environmental- friendly village planning, following the global trend of using new and renewable energy in world nations.

\section{RESEARCH METHOD AND THEORETICAL FRAMEWORK}

The present study used the surveyed data in the existing study (Nam and Kim 2007, 2008) on the three Korean traditional villages with about 100 houses about energy type which they are using for heating, cooking, and so on. Besides, this study analyzed energy potential on solar energy considering weather condition in the village and also estimated the total energy amount used in the village. As shown in Fig. 1, this paper analyzed benefit/cost $(\mathrm{B} / \mathrm{C})$ ratio through net present value (NPV) with various economical and environmental variables.

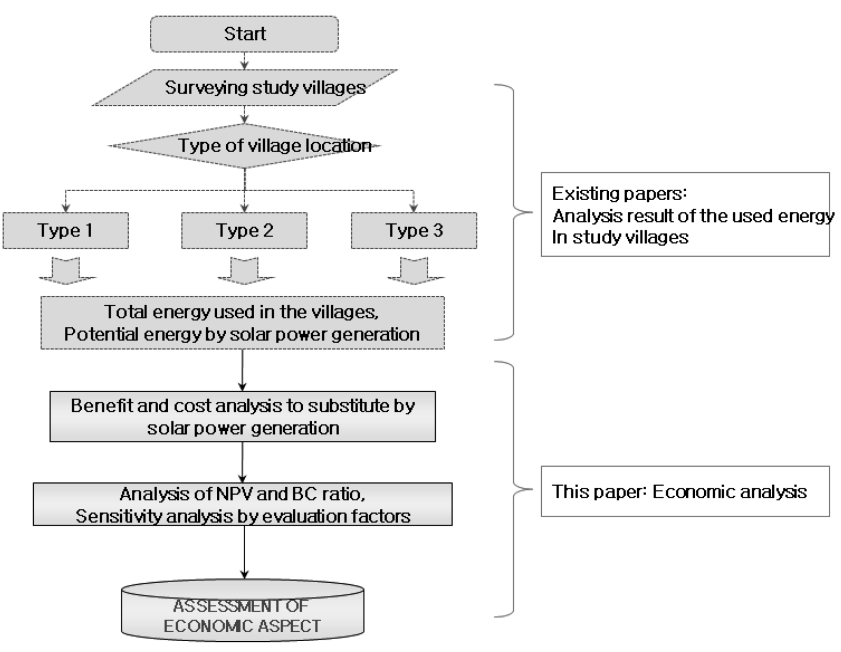

Fig. 1 Diagram for research process

Table 1 Specification of solar photovoltaic (PV) module*

\begin{tabular}{l|l|c}
\hline \multicolumn{2}{|c|}{ Item } & value \\
\hline \hline \multirow{4}{*}{ system } & type of solar radiation & poly-Si \\
\cline { 2 - 3 } & $\begin{array}{l}\text { absorption rate of solar energy } \\
\text { in transmission network }\end{array}$ & $95.0 \%$ \\
\hline \multirow{4}{*}{ PV module } & efficiency of nominal PV module & $11.0 \%$ \\
\cline { 2 - 3 } & temperature coefficient of PV & $0.40 \% /{ }^{\circ} \mathrm{C}$ \\
\cline { 2 - 3 } & loss rate of PV array & $5.0 \%$ \\
\cline { 2 - 3 } & power of PV array & $3.0 \mathrm{kWp}$ \\
\cline { 2 - 3 } & area of PV system & $27.3 \mathrm{~m}{ }^{2}$ \\
\hline \multirow{4}{*}{ solectricity control radiation array } & efficiency of mean invert & $90 \%$ \\
\cline { 2 - 3 } & invert capacity & $2.7 \mathrm{~kW} \mathrm{(AC)}$ \\
\cline { 2 - 3 } & loss rate of electricity control & $5 \%$ \\
\cline { 2 - 3 } & setting slope angle & $30^{\circ}$ \\
\hline & setting direction angle & $0^{\circ}($ south direction) \\
\hline
\end{tabular}

* Note: Kim et al. (2006)

\section{Power Generation by Solar Photovoltaic (PV)}

The total generation power $\left(E_{p}\right)$ by a PV system of Table 1, can be calculated by equation (1).

$$
E_{p}=\eta A_{p} Q_{A}
$$

where $E_{p}$ is total electricity power $(\mathrm{kWh}), \mathrm{n}$ denotes efficiency of generation, $A_{p}$ area of array $\left(\mathrm{m}^{2}\right)$, and $Q_{A}$ amount of solar radiation in slope $\left(\mathrm{kWh} / \mathrm{m}^{2}\right)$. The $\mathrm{PV}$ system has been developed as a form with capacity of 3 $\mathrm{kWp}$ to use for personal and public houses in Korea (Kim et al., 2006; Nam and Kim 2007, 2008). 


\section{Economical Analysis}

This study used the NPV and $\mathrm{BC}$ ratio method for economical analysis to the study villages. NPV and BC ratio can be calculated by equations (2) and (3), which mean difference and ratio of total benefit and total cost, respectively. In this method, especially, the environmental conservation factor is considered in the benefit factor (Kim, et al., 2006). This study followed such approach method. Thus, the total benefit can be estimated from the amount of electricity generation and the reduction amount of $\mathrm{CO}_{2}$ caused greenhouse effect, while the total cost can be calculated by construction and maintenance fee of the PV systems.

$N P V$

$=\sum_{i=0}^{n}\left[\frac{B(i)+G H G(i)}{(1+r)^{i}}\right]-\left[C_{0}+\sum_{i=0}^{n} \frac{O M(i)}{(1+r)^{i}}\right]$

\section{BCratio}

$=\sum_{i=0}^{n}\left[\frac{B(i)+G H G(i)}{(1+r)^{i}}\right] / \sum_{i=0}^{n}\left[C_{0}+\sum_{i=0}^{n} \frac{O M(i)}{(1+r)^{i}}\right]$

where $N P V$ is net present value for payback period year, $B(i)$ denotes income from the generated electricity by PV systems, $G H G(i)$ income from reduction amount of $\mathrm{CO}_{2}$ by using PV system instead of electricity generation of fossil fuel, $r$ discount rate (\%), CO initial investment cost, $O M(i)$ annual maintenance fee, and $n$ means payback period year.

\section{Application to case villages}

\section{Survey Data of Case Villages}

This study used the surveyed data of three study villages, Makhyunri, Boojangri, and Sosori, which located on counties of Kumsan and Dangjin, province of Chungnam. The study villages were selected as representative areas that can show different results between villages according to their location. The existing studies (Nam and Kim, 2007, 2008) analyzed energy consumption in the villages and potential of solar energy considering weather condition of the village site. The present study is using the both existing data of the energy consumption and potential in order to analyze economic aspect in the three villages. This paper analyzed the total amount of used energy per

Table 2 Analysis of energy amount per month used in the study village*

\begin{tabular}{c|r|r|r|r|r|r}
\hline \multirow{2}{*}{ month } & \multicolumn{6}{|c}{ electricity(kWh) } \\
\cline { 2 - 7 } & \multicolumn{2}{|c|}{ Makhyunri } & \multicolumn{2}{|c}{ Boojangri } & \multicolumn{2}{c}{ Sosori } \\
\cline { 2 - 7 } & per house & per village & per house & per village & per house & per village \\
\hline \hline 1 & 312 & 21,216 & 371 & 36,729 & 401 & 39,298 \\
\hline 2 & 311 & 21,148 & 370 & 36,630 & 401 & 39,298 \\
\hline 3 & 301 & 20,468 & 353 & 34,947 & 388 & 38,024 \\
\hline 4 & 302 & 20,536 & 356 & 35,244 & 392 & 38,416 \\
\hline 5 & 300 & 20,400 & 348 & 34,452 & 382 & 37,436 \\
\hline 6 & 300 & 20,400 & 351 & 34,749 & 386 & 37,828 \\
\hline 7 & 301 & 20,468 & 355 & 35,145 & 390 & 38,220 \\
\hline 8 & 320 & 21,760 & 382 & 37,818 & 407 & 39,886 \\
\hline 9 & 315 & 21,420 & 375 & 37,125 & 402 & 39,396 \\
\hline 10 & 301 & 20,468 & 354 & 35,046 & 390 & 38,220 \\
\hline 11 & 305 & 20,740 & 362 & 35,838 & 399 & 39,102 \\
\hline 12 & 310 & 21,080 & 368 & 36,432 & 400 & 39,200 \\
\hline sum & 3,678 & 250,104 & 4,345 & 430,155 & 4,738 & 464,324 \\
\hline
\end{tabular}

* Note: Nam and Kim (2008)

Table 3 Estimation of monthly electricity generation in study villages in unit module*

\begin{tabular}{|c|c|c|c|}
\hline \multirow[b]{2}{*}{ month } & Makhyunri & Boojangri & Sosori \\
\hline & $\begin{array}{l}\text { electricity } \\
(\mathrm{kWh} / \mathrm{m})\end{array}$ & $\begin{array}{c}\text { electricity } \\
(\mathrm{kWh} / \mathrm{m})\end{array}$ & $\begin{array}{l}\text { electricity } \\
(\mathrm{kWh} / \mathrm{m})\end{array}$ \\
\hline 1 & 497.5 & 294.5 & 535.8 \\
\hline 2 & 482.6 & 314.7 & 560.9 \\
\hline 3 & 611.1 & 391.9 & 757.8 \\
\hline 4 & 612.8 & 406.1 & 754.9 \\
\hline 5 & 661.0 & 417.8 & 849.7 \\
\hline 6 & 576.7 & 374.5 & 750.2 \\
\hline 7 & 500.3 & 320.2 & 617.7 \\
\hline 8 & 614.4 & 363.7 & 731.7 \\
\hline 9 & 584.5 & 367.5 & 761.8 \\
\hline 10 & 585.5 & 380.1 & 717.8 \\
\hline 11 & 515.5 & 273.9 & 531.7 \\
\hline 12 & 469.4 & 268.8 & 527.3 \\
\hline sum & 6711.2 & 4173.8 & 8097.4 \\
\hline
\end{tabular}

* Note: Nam and Kim (2008) 
month in the villages as shown in Table 2, considering the pattern of monthly home electric use supplied by Korea electric power cooperation (KEPCO, 2007).

\section{Analysis Results of Solar Energy Potential}

This study estimated the amount of electric power generation using the unit module in PV system, considering weather data on the study villages, as shown in Table 3 . The results showed that the highest value of electricity was generated in May, while the lowest value in December, for all villages. From Table 2 and 3, this study tried to analyze the energy balance in the village unit, considering the assumption that the village manager substitutes all energy used in the village to the electric power generated by PV systems.

\section{Results of Economical Analysis}

The analysis results of energy balance showed that the villages need to set the 38, 104, and 58 modules of PV system in order to meet the total energy consumption of the villages, Makhyunri, Boojangri, and Sosori as shown in Table 4, respectively. In the case of Makhyunri, for

Table 4 Potential of electricity in the study villages

\begin{tabular}{|c|c|c|c|c|c|c|c|c|c|c|c|c|}
\hline \multirow{6}{*}{ Month } & \multicolumn{12}{|c|}{ Village name } \\
\hline & \multicolumn{4}{|c|}{ Makhyunri } & \multicolumn{4}{|c|}{ Boojangri } & \multicolumn{4}{|c|}{ Sosori } \\
\hline & Item & $\begin{array}{c}\text { Unit } \\
\text { module }\end{array}$ & $\begin{array}{c}\text { Total } \\
\text { demand }\end{array}$ & \multirow{4}{*}{$\begin{array}{c}\text { Balance of } \\
\text { electricity } \\
(\mathrm{kWh})\end{array}$} & Item & $\begin{array}{c}\text { Unit } \\
\text { module }\end{array}$ & $\begin{array}{c}\text { Total } \\
\text { demand }\end{array}$ & \multirow{4}{*}{$\begin{array}{c}\text { Balance of } \\
\text { electricity } \\
(\mathrm{kWh})\end{array}$} & Item & $\begin{array}{c}\text { Unit } \\
\text { module }\end{array}$ & $\begin{array}{c}\text { Total } \\
\text { demand }\end{array}$ & \multirow{4}{*}{$\begin{array}{c}\text { Balance of } \\
\text { electricity } \\
(\mathrm{kWh})\end{array}$} \\
\hline & No. & 1 & 38 & & No. & 1 & 104 & & No. & 1 & 58 & \\
\hline & $\begin{array}{c}\text { Cost } \\
(1,000)\end{array}$ & 24,000 & 912,000 & & $\begin{array}{c}\text { Cost } \\
(1,000)\end{array}$ & 24,000 & 249,600 & & $\begin{array}{c}\text { Cost } \\
(1,000)\end{array}$ & 24,000 & 139,200 & \\
\hline & $\begin{array}{c}\text { Used } \\
\text { electricity } \\
(\mathrm{kWh})\end{array}$ & $\begin{array}{c}\text { Electric } \\
\text { generation } \\
(\mathrm{kWh})\end{array}$ & $\begin{array}{c}\text { Electric } \\
\text { generation } \\
(\mathrm{kWh})\end{array}$ & & $\begin{array}{c}\text { Used } \\
\text { electricity } \\
(\mathrm{kWh})\end{array}$ & $\begin{array}{c}\text { Electric } \\
\text { generation } \\
(\mathrm{kWh})\end{array}$ & $\begin{array}{c}\text { Electric } \\
\text { generation } \\
(\mathrm{kWh})\end{array}$ & & $\begin{array}{c}\text { Used } \\
\text { electricity } \\
(\mathrm{kWh})\end{array}$ & \begin{tabular}{|c|} 
Electric \\
generation \\
$(\mathrm{kWh})$
\end{tabular} & $\begin{array}{c}\text { Electric } \\
\text { generation } \\
(\mathrm{kWh})\end{array}$ & \\
\hline 1 & 21,216 & 497 & 18,905 & $-2,311$ & 36,729 & 295 & 30,633 & $-6,096$ & 39,298 & 536 & 31,079 & $-8,219$ \\
\hline 2 & 21,148 & 483 & 18,337 & $-2,811$ & 36,630 & 315 & 32,725 & $-3,905$ & 39,298 & 561 & 32,534 & $-6,764$ \\
\hline 3 & 20,468 & 611 & 23,221 & 2,753 & 34,947 & 392 & 40,753 & 5,806 & 38,024 & 758 & 43,953 & 5,929 \\
\hline 4 & 20,536 & 613 & 23,288 & 2,752 & 35,244 & 406 & 42,230 & 6,986 & 38,416 & 755 & 43,785 & 5,369 \\
\hline 5 & 20,400 & 661 & 25,119 & 4,719 & 34,452 & 418 & 43,452 & 9,000 & 37,436 & 850 & 49,285 & 11,849 \\
\hline 6 & 20,400 & 577 & 21,913 & 1,513 & 34,749 & 375 & 38,953 & 4,204 & 37,828 & 750 & 43,509 & 5,681 \\
\hline 7 & 20,468 & 500 & 19,011 & $-1,457$ & 35,145 & 320 & 33,306 & $-1,839$ & 38,220 & 618 & 35,828 & $-2,392$ \\
\hline 8 & 21,760 & 614 & 23,349 & 1,589 & 37,818 & 364 & 37,829 & 11 & 39,886 & 732 & 42,441 & 2,555 \\
\hline 9 & 21,420 & 585 & 22,211 & 791 & 37,125 & 367 & 38,219 & 1,094 & 39,396 & 762 & 44,182 & 4,786 \\
\hline 10 & 20,468 & 585 & 22,247 & 1,779 & 35,046 & 380 & 39,529 & 4,483 & 38,220 & 718 & 41,635 & 3,415 \\
\hline 11 & 20,740 & 515 & 19,588 & $-1,152$ & 35,838 & 274 & 28,487 & $-7,351$ & 39,102 & 532 & 30,836 & $-8,266$ \\
\hline 12 & 21,080 & 469 & 17,836 & $-3,244$ & 36,432 & 269 & 27,959 & $-8,473$ & 39,200 & 527 & 30,582 & $-8,618$ \\
\hline Sum & 250,104 & 6,711 & 255,025 & 4,921 & 430,155 & 4,174 & 434,075 & 3,920 & 464,324 & 8097 & 469,648 & 5,324 \\
\hline
\end{tabular}

Table 5 Input data for economic analysis using solar energy

\begin{tabular}{|c|c|c|c|c|c|c|c|}
\hline \multirow[b]{2}{*}{ Scenario } & \multicolumn{7}{|c|}{ Variables } \\
\hline & $\begin{array}{c}\text { Unit cost } \\
\text { for setting } \\
(1,000) \\
\end{array}$ & $\begin{array}{l}\text { Maintenance } \\
\text { rate }\end{array}$ & $\begin{array}{c}\text { Unit sale price } \\
\text { of electricity } \\
(1,000)\end{array}$ & $\begin{array}{l}\text { Increasing rate } \\
\text { of unit sale price }\end{array}$ & $\begin{array}{l}\text { Discount } \\
\text { rate }\end{array}$ & $\begin{array}{c}\text { Payback } \\
\text { period }\end{array}$ & $\begin{array}{c}\text { Income by } \\
\text { reduction of } \mathrm{CO}_{2} \\
(1,000)\end{array}$ \\
\hline Default* & $8,000 / \mathrm{kW}$ & $0.5 \%$ & $0.231 / \mathrm{kWh}$ & $1.1 \%$ & $6.5 \%$ & 25year & $0.00434 / \mathrm{kW}$ \\
\hline $\begin{array}{c}\text { Variation range } \\
\text { for sensitivity analysis }\end{array}$ & $\pm 50 \%$ & $\pm 50 \%$ & $\pm 50 \%$ & $\pm 50 \%$ & $\pm 50 \%$ & - & $\pm 50 \%$ \\
\hline
\end{tabular}

* Note: Kim et al. (2007) 
example, the 38 modules of PV system can generate $255,025 \mathrm{kWh}$ of electricity per year, which the total cost is $912,000,000$.

This study tried also to analyze economic effect for the PV system in order to generate electricity used in the villages, considering several factors for benefit and cost of Table 5 used by Kim et al. (2007). In analyzing condition, the present study performed the calculation of NPV and $B C$ ratio until the benefit is higher than the cost, which means plus value of NPV and bigger than 1.0 of BC ratio. The NPV results of Makhyunri, for instance, showed that the village need 41 years in order to have some benefit, 2,958,000 of NPV, in case of using the solar energy for their total energy per year, as shown in Table 6 , which $\mathrm{B} / \mathrm{C}$ ratio is higher than 1.0 after 41 years. As research of Choi, et al. (2009), this study used 25 years of payback period. In 25 years, two villages is less than zero of NPV, which means evaluation period, except of one village, Sosori, with plus value within that period. In the case that the government has subsidy policy giving $60 \%$ of the construction fee, the three villages have plus value in NPV within 25 years, as shown in Table 7.

\section{Sensitivity Analysis}

In this paper, the sensitivity of variables in equations of NPV and $\mathrm{BC}$ ratio was analyzed within $\pm 50 \%$ variation of the six variables such as Unit cost for setting (UCS), Maintenance rate (MR), Unit sale price of electricity (USP), Increase rate of unit sale price (IR), Discount rate (DR), and Income by reduction of $\mathrm{CO}_{2}$ (ICO) as defined in Table 5. The payback period was excepted in the sensitivity

Table 6 The NPV result of the study village using solar energy

\begin{tabular}{|c|c|c|c|c|c|c|c|}
\hline & \multirow{2}{*}{ Item } & \multicolumn{6}{|c|}{ Village name } \\
\hline & & \multicolumn{2}{|c|}{ Makhyunri } & \multicolumn{2}{|c|}{ Boojangri } & \multicolumn{2}{|c|}{ Sosori } \\
\hline \multirow{3}{*}{$\begin{array}{c}\text { Boundary condition } \\
\text { of analysis }\end{array}$} & No. of PV module & \multicolumn{2}{|c|}{38} & \multicolumn{2}{|c|}{104} & \multicolumn{2}{|c|}{58} \\
\hline & Setting cost $(1,000)$ & \multicolumn{2}{|c|}{912,000} & \multicolumn{2}{|c|}{249,600} & \multicolumn{2}{|c|}{139,200} \\
\hline & Generation of electricity (kWh) & \multicolumn{2}{|c|}{255,025} & \multicolumn{2}{|c|}{434,075} & \multicolumn{2}{|c|}{469,648} \\
\hline \multirow{5}{*}{$\begin{array}{l}\text { Analysis } \\
\text { in } 25 \text { years }\end{array}$} & Economic analysis & Benefit & Cost & Benefit & Cost & Benefit & Cost \\
\hline & Money $(1,000) *$ & 808,797 & 967,622 & $1,376,648$ & $2,648,230$ & $1,489,466$ & $1,476,897$ \\
\hline & NPV(1,000)* & \multicolumn{2}{|c|}{$-158,825$} & \multicolumn{2}{|c|}{$-1,271,582$} & \multicolumn{2}{|c|}{12,568} \\
\hline & $\mathrm{B} / \mathrm{C}$ ratio & \multicolumn{2}{|c|}{0.87} & \multicolumn{2}{|c|}{0.54} & \multicolumn{2}{|c|}{1.05} \\
\hline & Evaluation period(year) & \multicolumn{2}{|c|}{25} & \multicolumn{2}{|c|}{25} & \multicolumn{2}{|c|}{25} \\
\hline \multirow{4}{*}{$\begin{array}{c}\text { Analysis until } \\
\text { NPV value is bigger } \\
\text { than zero }\end{array}$} & Economic analysis & Benefit & Cost & Benefit & Cost & Benefit & Cost \\
\hline & Money $(1,000) *$ & 979,807 & 976,848 & $1,881,365$ & $2,687,646$ & $1,489,466$ & $1,476,897$ \\
\hline & $\operatorname{NPV}(1,000) *$ & \multicolumn{2}{|c|}{2,958} & \multicolumn{2}{|c|}{$-806,281$} & \multicolumn{2}{|c|}{12,568} \\
\hline & Evaluation period(year) & \multicolumn{2}{|c|}{41} & \multicolumn{2}{|c|}{$>100$} & \multicolumn{2}{|c|}{25} \\
\hline
\end{tabular}

* Note: Net present value

Table 7 The NPV result of the study villages using solar energy and considering $60 \%$ of subsidy from the government

\begin{tabular}{|c|c|c|c|c|c|c|c|}
\hline \multirow{2}{*}{\multicolumn{2}{|c|}{ Item }} & \multicolumn{6}{|c|}{ Village name } \\
\hline & & \multicolumn{2}{|c|}{ Makhyunri } & \multicolumn{2}{|c|}{ Boojangri } & \multicolumn{2}{|c|}{ Sosori } \\
\hline \multirow{3}{*}{$\begin{array}{l}\text { Boundary } \\
\text { condition } \\
\text { of analysis }\end{array}$} & No. of PV module & \multicolumn{2}{|c|}{38} & \multicolumn{2}{|c|}{104} & \multicolumn{2}{|c|}{58} \\
\hline & Setting cost $(1,000)$ & \multicolumn{2}{|c|}{36,480} & \multicolumn{2}{|c|}{99,840} & \multicolumn{2}{|c|}{55,680} \\
\hline & Generation of electricity (kWh) & \multicolumn{2}{|c|}{255,025} & \multicolumn{2}{|c|}{434,075} & \multicolumn{2}{|c|}{469,648} \\
\hline \multirow{4}{*}{$\begin{array}{l}\text { Analysis until } \\
\text { NPV value is bigger } \\
\text { than zero }\end{array}$} & Economic analysis & Benefit & Cost & Benefit & Cost & Benefit & Cost \\
\hline & Money $(1,000) *$ & 415,613 & 395,151 & $1,150,292$ & $1,128,597$ & 624,843 & 594,972 \\
\hline & $\mathrm{NPV}(1,000) *$ & \multicolumn{2}{|c|}{20,461} & \multicolumn{2}{|c|}{21,695} & \multicolumn{2}{|c|}{29,870} \\
\hline & Evaluation period(year) & \multicolumn{2}{|c|}{9} & \multicolumn{2}{|c|}{19} & \multicolumn{2}{|c|}{8} \\
\hline
\end{tabular}

* Note: Net present value 
Table 8 Sensitivity analysis with variation of input factors

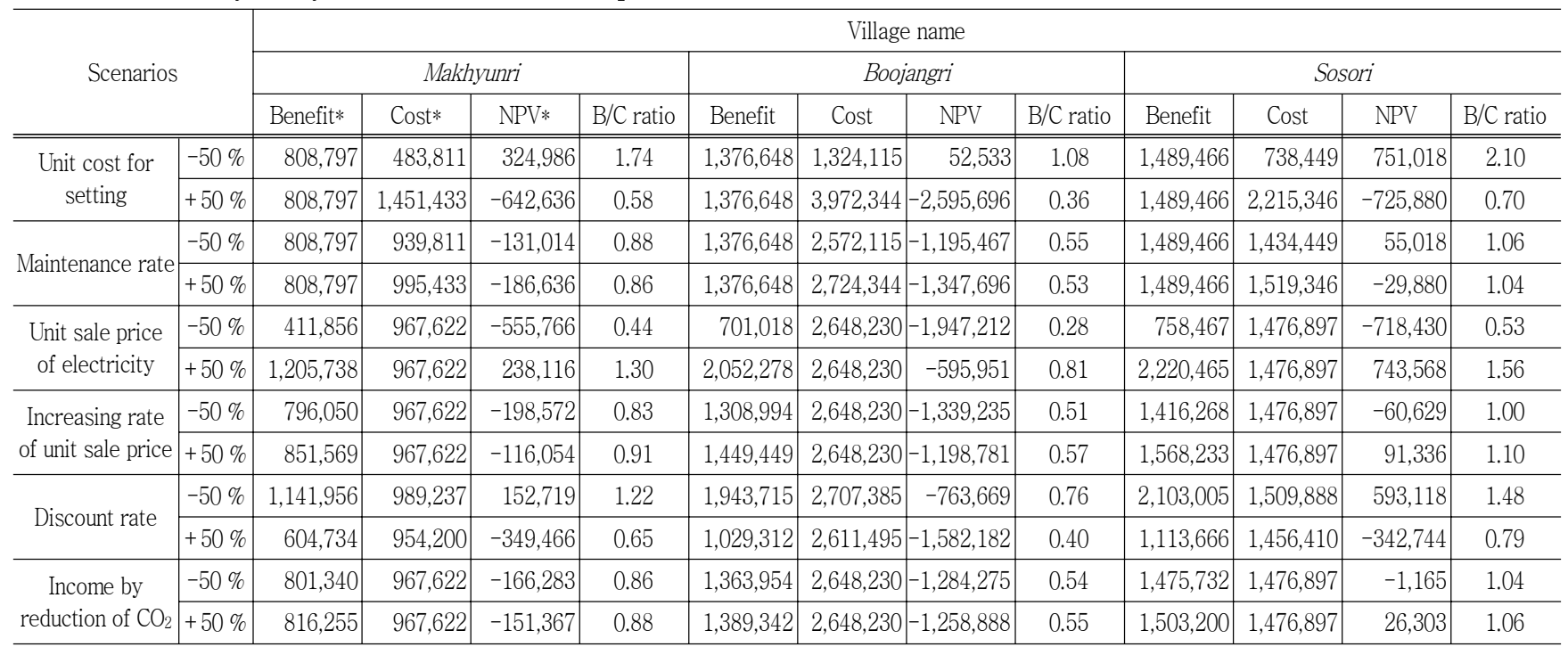

* Note: Net present value

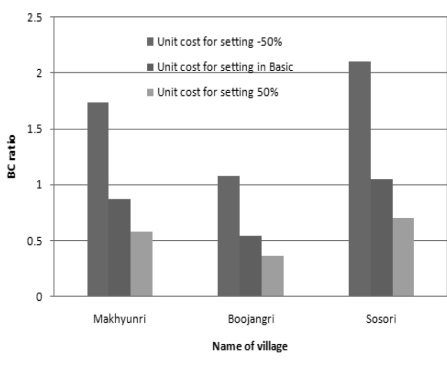

(a) Unit cost

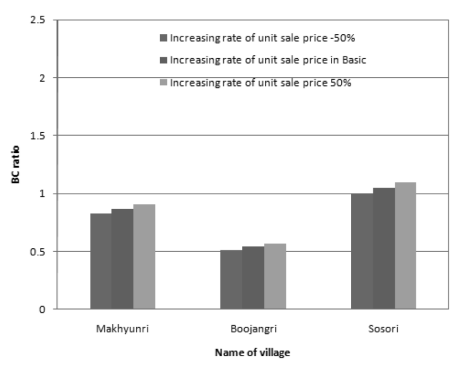

(d) Increasing rate

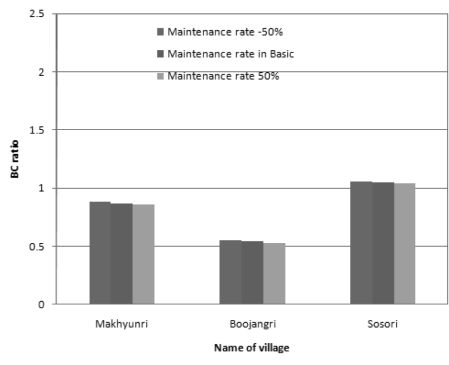

(b) Maintenance rate

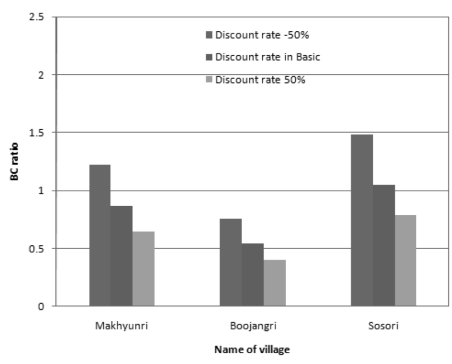

(e) Discount rate

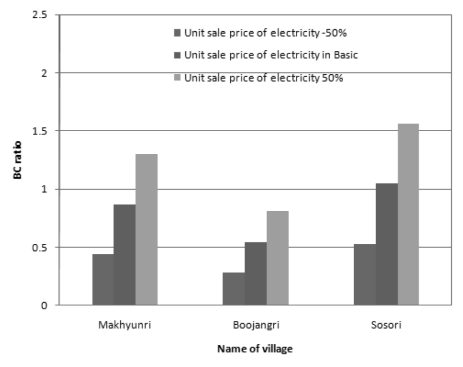

(c) Unit sale price

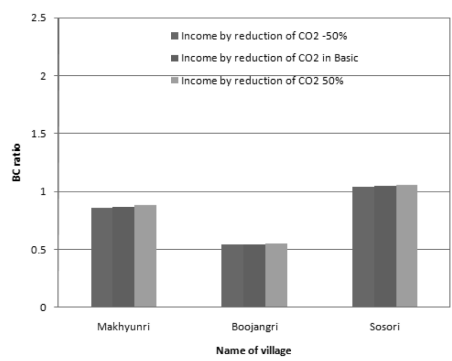

(f) Income by reduction of $\mathrm{CO}_{2}$

Fig. 2 Sensitivity analysis of BC ratio for several scenarios

analysis because it was already used for generation of the minimum period showing plus value of NPV within 100 year, as shown in Table 6. The basic input data of Table 5 used by Kim et al. (2007) were used as the default values of each variable for the sensitivity analysis. Considered the NPV and BC ratio of Table 8 and Fig. 2, UCS has the highest variation in NPV and $\mathrm{BC}$ ratio, followed by USP and DR, while the others have low variation in all villages. Meanwhile, the cases with plus value of NPV and bigger than 1.0 of $\mathrm{BC}$ ratio were founded at several scenarios such as $-50 \%$ of UCS, 50 $\%$ of USP, and $-50 \%$ of DR in Makhyunri, $-50 \%$ of UCS in Boojangri, and except of $50 \%$ of UCS, $-50 \%$ of USP, and $50 \%$ of DR in Sosori, respectively. 


\section{Discussion}

The present analyzed the economic benefit and cost by using the surveyed village data and the estimate potential electricity power from solar energy. The results showed that there was economic benefit in the cases of using the solar energy to make green-village planning, but not so much in evaluation period of 25 years without subsidy of the government. The problem of fossil energy in the future, however, will make the renewable energy to be very useful, if several factors, such as increasing oil price and greenhouse effect of $\mathrm{CO}_{2}$, can be considered. Therefore, considered the present condition on government policy for rural village, the application of renewable energy to rural village has several issues that should be resolved in research aspect. The government subsidy policy for using renewable energy should be taken to make greenvillage planning. Actually, in the sensitivity analysis to \pm 50 $\%$ variation of six factors (Unit cost for setting, Maintenance rate, Unit sale price of electricity, Increasing rate of unit sale price, Discount rate, and Income by reduction of $\mathrm{CO}_{2}$ ), many cases with values of $\mathrm{BC}$ ratio bigger than 1.0 were simulated. This results designate that the application of solar energy in rural villages is very useful in economical aspect, if the government subsidy and the consumption and price trend of fossil energy are considered.

\section{SUMMARY AND CONCLUSION}

This study aimed to analyze the balance of energy and economic analysis to the study villages, Makhyunri, Boojangri, and Sosori, which located on province of Chungnam, in the case of green-village planning using solar energy.

Economic analysis was performed with the NPV method from the benefit and the cost, which are calculated by the potential and the used energy in the villages. This study established the category of economical analysis that the number of PV systems is increasing continuously until the total potential generated by solar energy can be higher than the total energy used in the village. When the energy balance of consumption and generation meets the economic evaluation, which $\mathrm{BC}$ ratio is higher than
1.0, this study calculated NPV and its corresponding evaluation period. The evaluation results of economic analysis showed that the number of PV systems with capacity of $3 \mathrm{~kW}$ in the three villages was various and different from villages due to their different weather condition.

From the economic analysis, it designated that the two study villages in economic aspect can not be substituted their requirement of energy by the generation power of solar energy in 25 years, except of one village, Sosori. One village, Makhyunri, has economic benefit within evaluation period of 41 years, while Boojangri does not have economic effect even more than 100 years. Considered the government has subsidy policy giving $60 \%$ of the construction fee, the three villages have plus value in NPV within 25 years. This study has new findings that some village has high economic effect according to its locational condition.

In the sensitivity analysis to $\pm 50 \%$ variation of several factors in NPV and $\mathrm{BC}$ ratio equations, this study also found that there are economical effect and benefit in the application of solar energy to rural villages, if the government subsidy and the consumption and price trend of fossil energy are considered.

From the above results, this study has concerned that not only this renewable energy should be used for the future of earth, but also there will be economic benefit if various factors such as increasing international oil price and greenhouse effect with $\mathrm{CO}_{2}$ by using fossil energy are considered. Thus, the government needs to make some policy to promote using renewable energy for green-village planning to rural villages with high potential of solar energy.

\section{REFERENCES}

1. Choi, J. M., J. W. Ju, and D. G. Kim, 2009. A study on the economic evaluation of photovoltaic system in the residential building. Journal of the Korean Solar Energy Society 29(6): 14-21.

2. Jo, D. K., I. S. Chun, M. S. Jeon, and C. M. Auh, 2001. A study on the analysis of solar radiation on inclined surfaces. Journal of the Korean Solar Energy 
Society 21(3): 19-24.

3. Jo, D. K. and Y. H. Kang, 2007. A study on the analysis of solar radiation components for the installation of concentrating photovoltaic system. Journal of the Korean Solar Energy Society 27(2): 53-59.

4. Ju, H. L., J. W. Park, U. C. Shin, and N. C. Baek, 2006. Experiment study on long-term thermal performance of active solar hot water heating system of dormitory. Architecture \& Urban Research Information Center. http://www.auric.or.kr, 41-46.

5. Kim, D. S. and S. W. Nam, 2008. Economic analysis on rural green-village considering solar energy in Korea. 6th International Agricultural Engineering Conference and Exhibition, 53.

6. Kim, M. C., J. W. Ju, G. H. Seo, K. H. Lee, and J. M. Choi, 2007. The assessment of payback period for the photovoltaic system in residential building. Journal of the Korean Solar Energy Society 27(2): 87-93.

7. Kim, M. R. and J. O. Yoon, 2006. The green-village design on the main application of the energy source using wind turbine system, Architecture \& Urban Research Information Center, http://www.auric.or.kr, 139-147.

8. Kim, Y. K., T. W. Lee and K. E. Yoon, 2006. The performance evaluation on the winter season of the solar heating system using CPC solar collectors integrated the roof of a residential building. 2006 conference of the Korean Solar Energy Society, 126-131.
9. Korea Electric Power Corporation (KEPCO), 2007. Electric statistics 1991-2006. www.kepco.co.kr,

10. Lee, S. N. and Y. H. Kang, 2006. Study on long-term performance characteristics of various solar thermal system for heating protected horticulture system. Journal of the Korean Solar Energy Society 26(3): $1-8$.

11. Ministry of Agriculture \& Forestry (MAF), 2007. A study on the application of renewable energy in rural villages, 54-140.

12. Nam, S. W., 2006. The effect of soil warming on the Greenhouse heating load. Journal of the Korean Society of Agricultural Engineers 48(5): 51-60.

13. Nam, S. W. and D. S. Kim, 2007. An investigation and analysis on actual condition of energy utilizations in farmhouse for environmental-friendly planning of rural villages. Journal of Korean Society of Rural Planning 49(6): 55-62.

14. Nam, S. W. and D. S. Kim, 2008. A study on the application of renewable energy for environmentalfriendly planning of rural villages - analysis of solar energy resources - . Journal of the Korean Society of Agricultural Engineers 50(3): 105-114. 